Article

\title{
The Kleinhaus and the Politics of Localism in German Architecture and Planning, c. 1910
}

\author{
Isabel Rousset \\ School of Design and the Built Environment, Curtin University, Australia; isabel.rousset@curtin.edu.au
}

Submitted: 17 August 2021 | Accepted: 3 December 2021 | Published: 31 March 2022

\begin{abstract}
As an antidote to the substandard tenement apartment, the ideal of the "small house" (Kleinhaus) was ubiquitous in housing debates in Germany before World War One. Denoting a modestly sized two-story family house aligned with the street, it had its origins in the Middle Ages, during which it was constructed to serve the humble domestic needs of urban craftsmen who lived and worked in thriving trade cities including Lübeck, Bremen, Hamburg, Augsburg, Nuremberg, and Ulm. For modern promoters of low-density alternatives to the tenement, the Kleinhaus was an ideal model for mass appropriation. Unlike foreign and untranslatable dwelling models like the "villa" and the "cottage," the Kleinhaus conveyed something that was both urban and quintessentially Germanic. It was thus enlisted by housing reformers to strengthen local cultural identity whilst raising the standards of the nation's housing stock. This article examines the significance of the Kleinhaus in fostering dialogue between the fields of architecture and planning, and considers its embeddedness in a wider project of cultural nationalism in pre-war Germany.
\end{abstract}

\section{Keywords}

affordable housing; architectural typology; cottage; family; Germany; Heimat; localism; nationalism; photography; urban design

Issue

This article is part of the issue "The Terms of Dwelling: Re-Theorizing Housing Through Architecture" edited by Yael Allweil (Technion-Israel Institute of Technology) and Gaia Caramellino (Politecnico di Milano).

(C) 2022 by the author(s); licensee Cogitatio (Lisbon, Portugal). This article is licensed under a Creative Commons Attribution 4.0 International License (CC BY).

\section{Introduction}

After stumbling off the main road of Glockengießerstrasse and encountering them in a narrow alley, one could be forgiven for momentarily forgetting one's urban location in the center of Lübeck's old town (Figure 1). Unified by a plain coat of whitewash and a generous pitched roof, these alley houses exemplified a residential type that by the early 20th century came to be known as the "small house" (Kleinhaus). The Kleinhaus typically described a house of no more than two stories, which could be detached, duplex, or terraced, but which was easily recognizable as a self-contained single-family unit by the presence of three windows and a separate entry that was aligned directly with the street-usually a cozy residential path concealed from the main traffic artery. Clad in brick or plaster and featuring a shingled pitched roof with dormers and a chimney, its exterior was necessarily modest and contained minimal ornamentation. The exemplary Kleinhaus was likewise economical in plan, featuring usually no more than four rooms, with a combined kitchen and living room as the locus of family life on the ground floor and separate bedrooms for parents and children on the upper floor. It sometimes contained a small private garden with a stable to accommodate a few chickens and perhaps even a goat (Behrendt, 1916, pp. 210-212).

Relics of late medieval and early modern planning, residential quarters of Kleinhäuser ("small houses") could still easily be found in historic trade cities like Lübeck, Bremen, Hamburg, Augsburg, Nuremberg, and Ulm in the late 19th century, even after frequent outbreaks of cholera led many reformers to decry their presence in the name of public health. They received 
renewed appreciation in the first decade of the 20th century, initially amongst art historians and conservative promoters of heritage protection, but increasingly amongst urban reformers and architects who saw in the Kleinhaus an ideal dwelling type that could provide a more locally-inflected solution to the much debated "housing question." By examining the presence of the Kleinhaus in housing debates, this article establishes the turn to localism as a constitutive feature of German architectural modernism and the nascent field of planning. From its historical rediscovery to its codification in planning, the Kleinhaus became a powerful nationalistic tool to reinscribe traditional values of the family and community into the fabric of modern urban society.

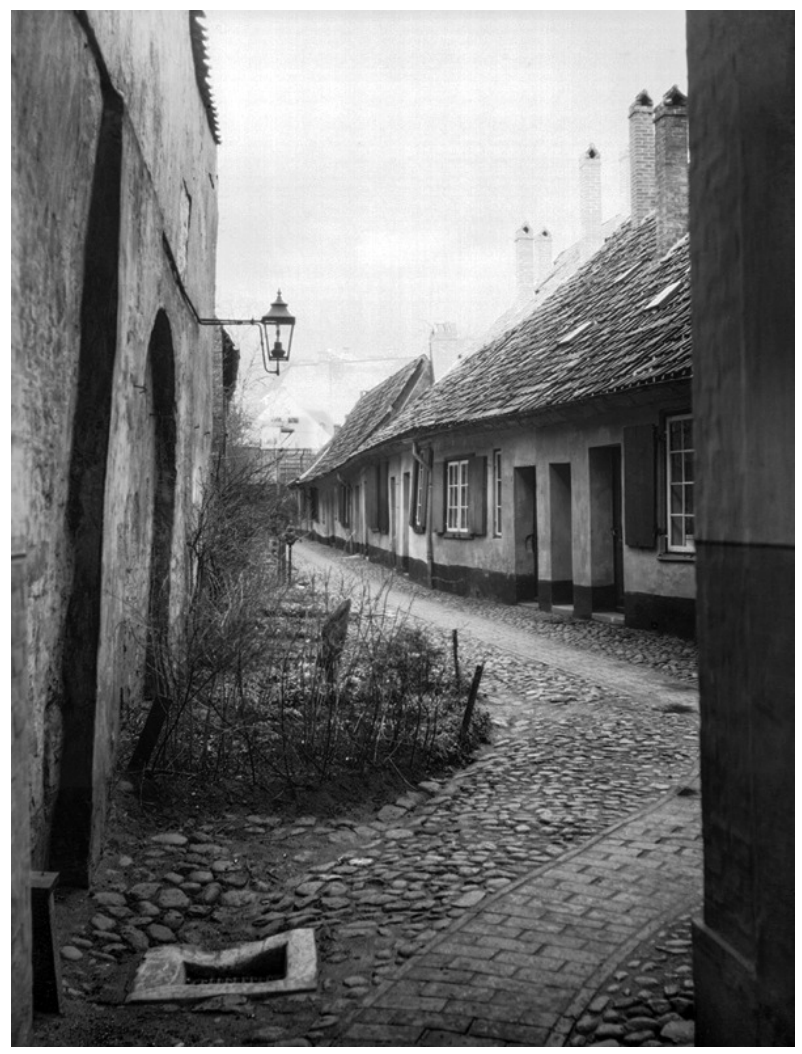

Figure 1. Residential lane off Glockengießerstraße 41-3, Lübeck, constructed in 1612. Source: "Gandorps Gang Hof" [Gandorps Gang - Courtyard] (1925), (C) Bildarchiv Foto Marburg.

\section{Discovering Heimat}

Late 19th-century German architectural culture can largely be characterized by the growth of national selfconsciousness and a widespread desire to rediscover historical building and applied arts traditions. From the work of amateur photographers to anthropologists, efforts to document and codify national dwelling styles were widespread and engaged diverse layers of the population. In these efforts, Germany was certainly not alone. Amongst the nations of Central Europe keen to shed the influence of French academicism, the discovery of national folkloric artifacts, such as simple houses and their material contents, proved to be a widespread phenomenon in the larger global process of nationbuilding (Baycroft \& Hopkin, 2012). In Germany, the localism movement was encapsulated in the pervasive term "Heimat" (homeland). While the term still largely holds connotations of nostalgia and mourning over the loss of cultural tradition, historians have nonetheless shown it to be an ideologically multivalent phenomenon that helped German citizens construct a national identity based on cultural pluralism and regional heterogeneity (Applegate, 1990). The Heimat movement left its most tangible mark on literature, painting, music, and indeed architecture, but its influence in German society ran much deeper, shaping debates ranging from environmental protection to the design of school curriculum (Blackbourn \& Retallack, 2007; Jenkins, 2003; Rollins, 1997).

In the sphere of architectural history, a growing body of literature has established the pervasiveness of localist thinking amongst modern German architects and urbanists (Jerram, 2007; Lampugnani \& Schneider, 1992; Rousset, in press; Umbach, 2009). From "national romanticism" to "architectural nationalism" to "vernacular modernism," present architectural historiography offers a wealth of conceptualizations that have generated nuanced perspectives on German society's hunger for tradition in the late 19th century and beyond (Miller-Lane, 2000; Schwarzer, 2016; Umbach \& Hüppauf, 2005). However, the influence of Heimat in the spheres of housing and urban planning is less understoodperhaps because the term "mass housing" is habitually taken in architecture to mean houses that aesthetically express a modernizing process of social abstraction that devours traditional social order and the possibility of placeness. Yet, when the professional discipline of planning (Städtebau) was born in Germany in the early 20th century, it was, from the beginning, deeply committed to the study of traditional local social housing models that could act as design prompts for new urban developments.

Photography quickly became the favored tool for documenting local architecture amongst amateur Heimat enthusiasts and heritage professionals alike (Joschke \& Brown, 2012). Beginning in the 1880s with the founding of the field of "house research" (Hausforschung), books on pre-modern northern European dwelling cultures were rife but were largely limited to reproducing diagrams, drawings, and old artworks depicting traditional dwellings (see, e.g., Essenwein, 1892; Stiehl, 1908). Architectural photography was already well established in Europe, especially in France and England via programs to document national monuments, especially churches (Ackerman, 2002). The increased use of the magic lantern projector in educational departments in art history across Europe and the United States at the end of the 19th century created wide markets for photographic slides depicting works of art and architecture. A student of art historian Herman Grimm (among 
the first to integrate slides into art history lectures), the photographer and art historian Franz Stoedtner amassed a huge collection of photographic slides from his travels around Germany. In 1895, he established the Institute for the Science of Projection Photography (Institut für wissenschaftliche Projektionsphotographie), an agency specializing in art and architecture slides for reproduction in lectures and publications (the collection now forms the core of the Bildarchiv Foto Marburg; Buchkremer, 2013, pp. 386-387).

One of Stoedtner's most popular collections dealt exclusively with the new field of urban design (Städtebaukunst). This collection included around 800 photographs of old urban maps, artistic panoramas, and original photographs of historic city streets. Where the Austrian art teacher Camillo Sitte traveled to Italy to hand-sketch piazzas from watchtowers in order to write his famed handbook on city planning (Lampugnani, 2009, p. 26; Sitte, 1889), with the help of Stoedtner's and other similar collections, books on urban design history could be written at a rapid pace. This new genre of documentary photography turned old German cities into sites of important lessons for young architects. Notions of authenticity and genius loci in architecture were hitherto typically attached to rural farmhouses that spoke to what was perceived to be the heart of the nationthe peasanty (Redensek, 2017). The growth of an urban design photographic archive cultivated new interest in buildings that captured the activities of a thriving class of urban merchants and craftsmen who forged Germany's path into the early modern world.

The simultaneous invention of halftone printing in the 1890s allowed photographs to be printed cheaply and effectively alongside text, and a market quickly emerged for photographic books on local urban building traditions. The two best-known books were undeniably architect and conservative ideologue
Paul Schultze-Naumburg's volume Kulturarbeiten: Der Städtebau [Cultural Works: City Planning] (1906) and architect Paul Mebes's (1908) Um 1800 [Around 1800]. Both collections celebrated the modest, matter-of-fact style of middle-class domestic architecture that characterized early 19-century German cities. The threevolume Die schöne deutsche Stadt [Beautiful German Cities] (Baum, 1912; Wolf, 1911, 1913) utilized a wealth of materials amassed from slide agencies, heritage protection enthusiasts, and amateur photographers to offer a wide-ranging survey of simple domestic building traditions dating back to the Middle Ages. The goal of these and similar volumes was to extend popular appreciation for Heimat, but also to train the architect's eye in identifying classic Sittean urban design principles, including picturesque grouping and enclosed intimate streets. These books were not intended to be encyclopaedic or especially historically rigorous. Their textual contents offered little in the way of art-historical precision, typically eschewing details like construction dates, builder names, styles, and building types. They were principally designed for readers to immerse themselves in the images and intuit from them a modern spirit of objectivity.

A handful of old philanthropic residential complexes emerged in photographic urban design literature as exemplary models for new housing construction. At the onset of the early modern world, philanthropic housing arose in response to the growing financial wealth of patricians in German trading cities, whose religious sense of obligation drove them to establish foundations to serve the lower stratum of urban society (Tietz-Strödel, 1982, pp. 6-26). Popular in the Hanseatic cities of Hamburg, Bremen, and Lübeck were "dwelling corridors" (Wohngänge), that could be found tucked away in narrow block interiors (Figure 2; Kohlmorgen, 1982). They typically housed widows of merchants and boatsmen
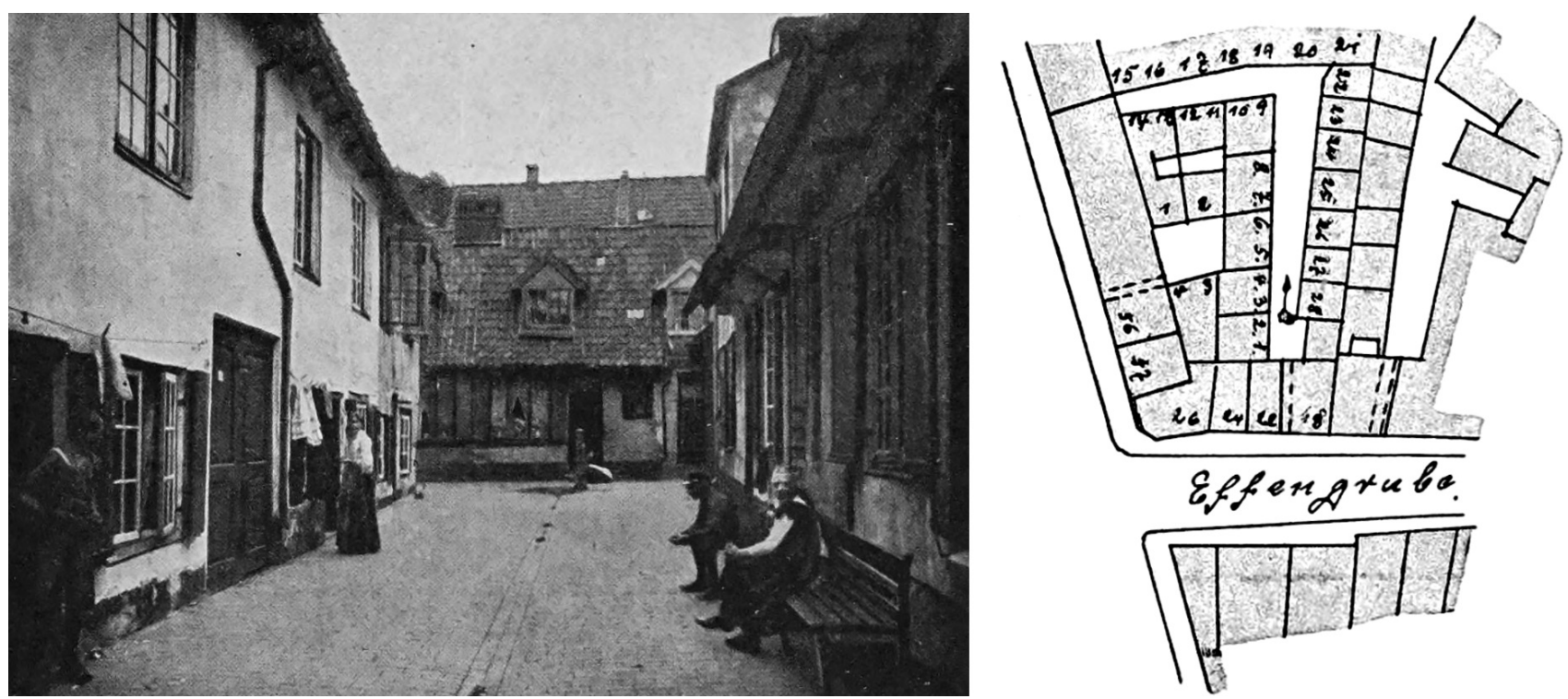

Figure 2. Photograph and plan of Blohmsgang dwelling corridor in Lübeck. Source: Harms (1907, plate 86). 
and were named in honor of their wealthy donors. Lübeck boasted the best-preserved dwelling corridors (Bruns, 1920, pp. 38-40), including Glandorps Hof (1612) and Füchtings Hof (1649).

Modern critics considered these dwelling corridors to be exemplary works of socially-relevant urban design: They were suitably economical to reflect the modest means of their occupants, but likewise picturesque and cozy in their interiority and subtle positioning off the busy traffic road (Behrendt, 1916, pp. 216-220; Wolf, 1913). Built ad-hoc as infill in the block interior, these spaces might not appear to differ much from the notorious tenement block courtyards that characterized densely populated cities like Berlin. But in the eyes of reformers, philanthropic dwelling corridors were more than mere empty voids. Lined with flower beds and sitting benches where neighbors could gossip, they were imbued with rhythm and character. A personal groundlevel entry into each two-story house offered a humane scale and individualizing element for residents, while the houses' positioning in united rows gave the complex a transpersonal feeling, avoiding the bourgeois tendency for individual aggrandizement through elaborate ornamental features. As one critic noted in reference to Füchtings Hof, the dwelling corridor felt like a city within a city, forming a "little realm of its own" (Bruns, 1920, p. 38).

Images of other notable housing complexes in UIm and Nuremberg built to accommodate single families were also circulated via Stoedtner's collection, further capturing the aesthetic of the socially-informed row house type. Built in 1488 to accommodate the families of Swabian fustian weavers brought in to bolster the city's textile trade (Schnelbögl, 1961), the Nuremberg housing complex aptly named "Seven Rows" (Sieben Zeilen; Figure 3) featured rows of three small two-story dwellings with entries located on quieter lanes off the main streets, which could serve as play areas for chil- dren. It is not difficult to speculate on what modern observers might have been expected to learn through Seven Rows: While suitably integrated into the existing cityscape, they appear distinctly ready-made, offering a glimpse of what contextually-sensitive standardized and rationalized modern housing might look like. A 1620 project in UIm that provided housing for families of the city's militia was also significant (Figure 4). This project absorbed many of the tactics of Lübeck's ad-hoc corridors in a more systematized and standardized fashion, integrating the principle of the quiet residential street into an entire housing quarter, in effect developing the modern notion of the residential community or "neighborhood unit." The architecture follows a familiar formula, with the austerity of the plain-coated exterior offset by generously pitched roofs that assert a distinctly domestic feeling.

The Fuggerei housing complex in Augsburg garnered the most attention in urban design literature (Figure 5; Baum, 1912, p. 113; Schultze-Naumburg, 1906, p. 62). Established in 1516 by the notable Fugger banking family and carried out by the master-builder Thomas Krebs, it provided cheap rental accommodation for the city's poor craftsmen and their families. Containing 52 single-family dwellings, the residential complex brought together many notable principles that account for its positive reception amongst early 20th-century planners (Tietz-Strödel, 1982, p. 48). The layout of its free-standing rows conveyed a modern attitude of good economy, modest means, and mass standardization, while two gated entries (locked every evening) gave the complex a closed-off and communal spirit. More innovatively, it accommodated back gardens for each house, ensuring privacy and a degree of self-sufficiency for every family. Its dwelling plans were also highly rationalized. Local Augsburg historian Joseph Weidenbacher identified three main types of dwellings in the Fuggerei, ranging from dwellings with a kitchen and two rooms to
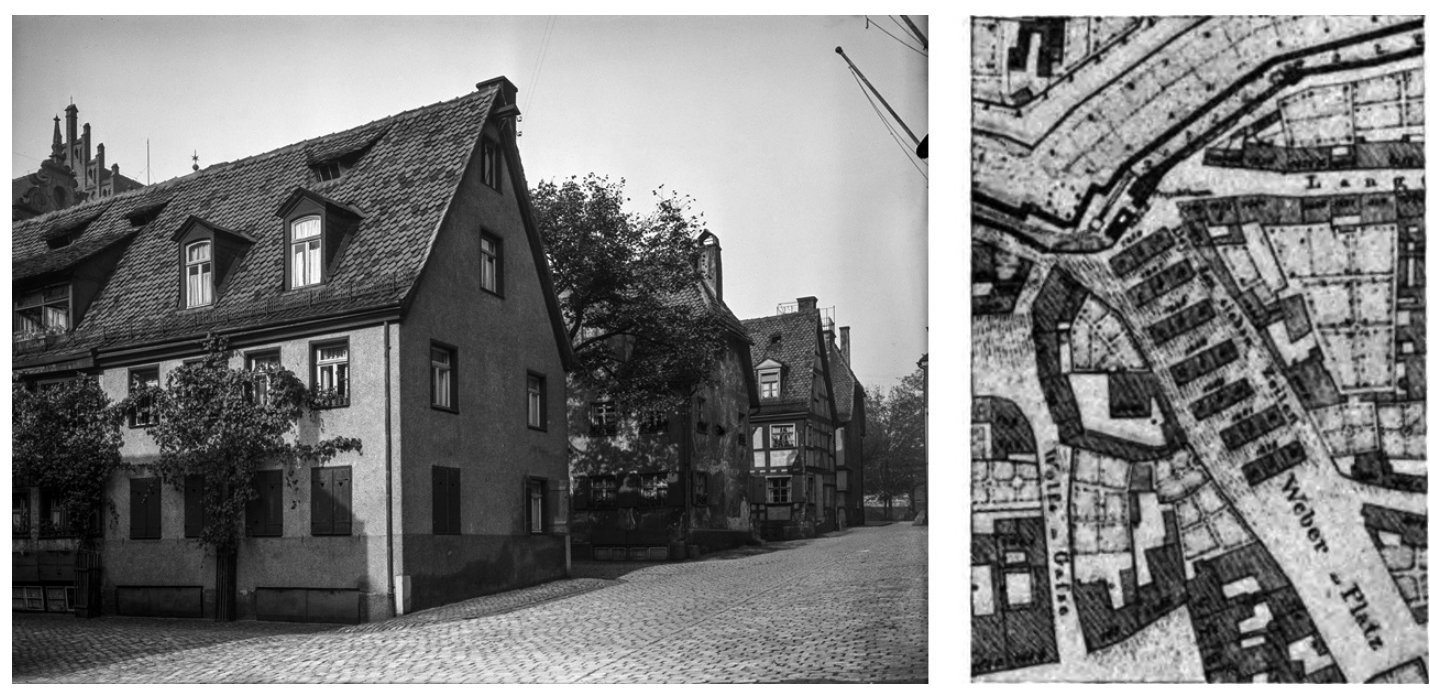

Figure 3. Left: Photograph of Nuremberg's Seven Rows. Right: Map highlighting the Seven Rows. Sources: "Sieben Zeilen" [Seven Rows] (1918, (c) Bildarchiv Foto Marburg) and Kuhn (1921, p. 102). 

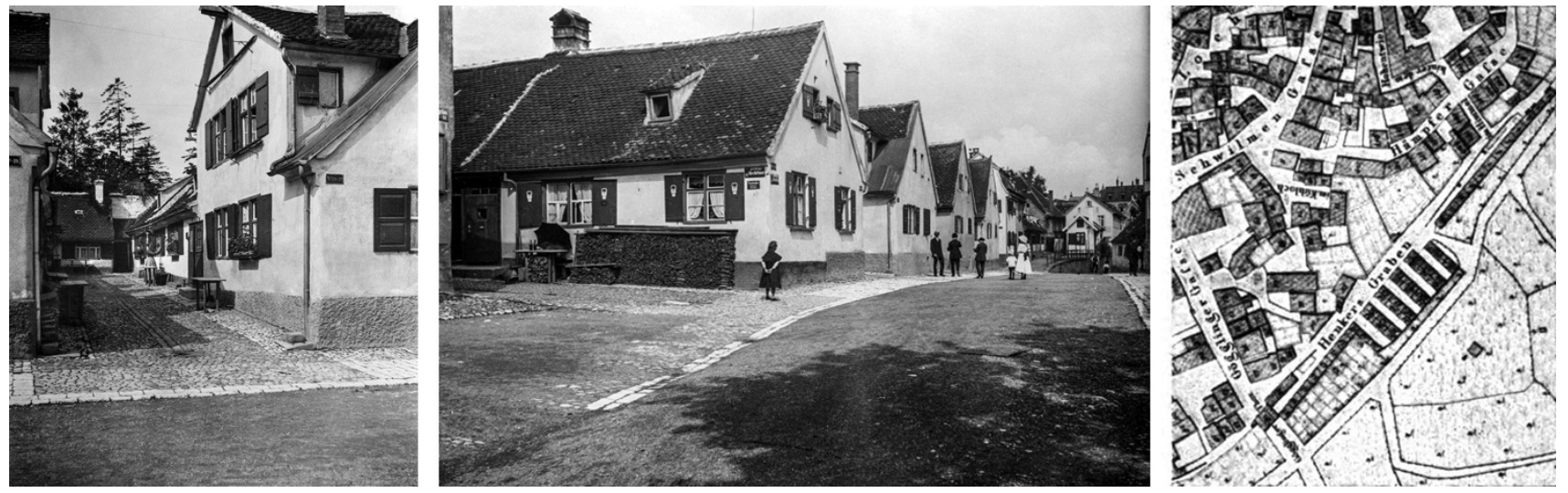

Figure 4. Left and center: Photographs of Ulm's militia housing quarter from the collection of Franz Stoedtner. Right: Map highlighting Ulm's militia housing on the border of the city wall. Sources: "Soldatenhäuser" [Soldiers' Housing] (1900, (C) Bildarchiv Foto Marburg) and Kuhn (1921, p. 105).

dwellings with a kitchen, chamber, and three rooms. Guided by the "innate benevolent spirit" and "working ethos" of the Fugger family, the economical rationale that underpinned the Fuggerei, for Weidenbacher (1918), made it an ideal model for new workers' housing.

The Fuggerei was also socially significant because it was the first philanthropic entity to be bound to an independent housing foundation rather than to an existing religious body (Adam, 2016, p. 3). Unlike the housing projects in Ulm or Nuremberg, it did not serve a particular civic institution or trade. While philanthropic housing across Europe in the early modern era typically served single people whose circumstances caused them to seek institutional aid (such as widows, nuns, or the sick) the Fuggerei purely served families by virtue of their work-

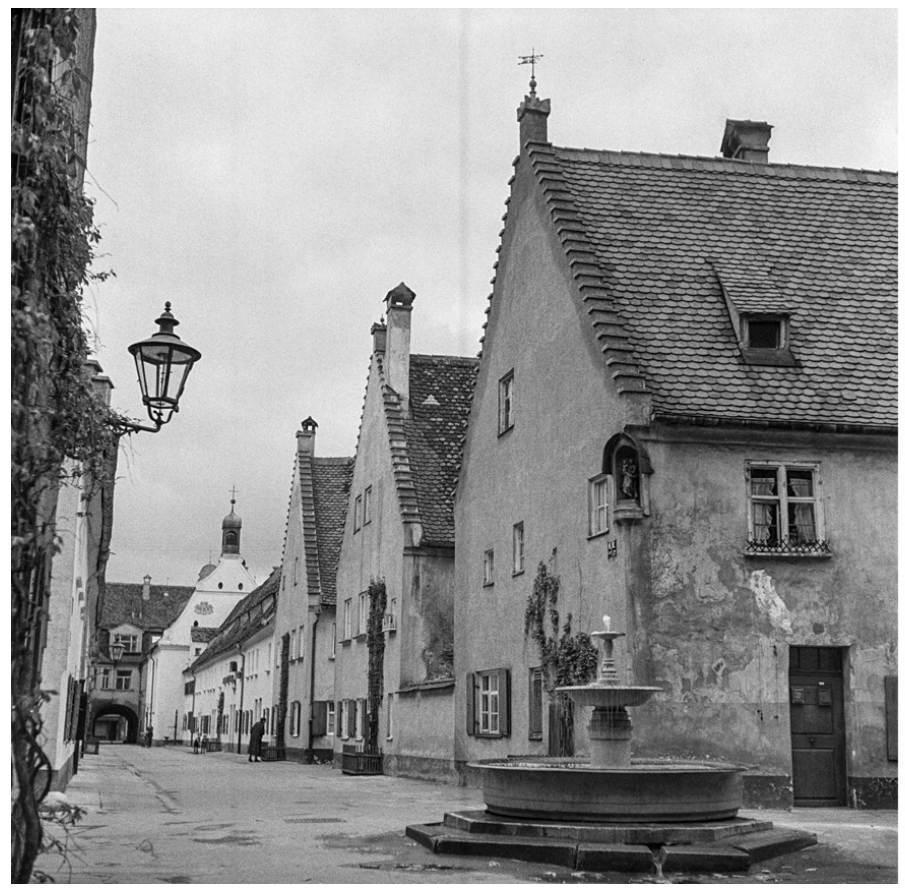

ing ethos and belonging to the city. As such, the housing complex was unique in operating as a preventative mechanism that symbolically placed the secular institution of the family at the heart of modern urban society.

\section{Terming the Kleinhaus}

The housing models cited above reflected values that ran contrary to established planning practice in Germany. Since the publication of German planner Josef Stübben's canonical handbook Der Städtebau [City Planning] in 1890 , the field of planning expressed little concern for housing design, remaining devoted to issues of street traffic and hygiene. In imitation of Haussmann's Paris, Stübben promoted a schematic Baroque aesthetic as a

Figure 5. Left: Photograph depicting a street in the Fuggerei. Right: Map highlighting the plan of the Fuggerei. Sources: Aufsberg (1939, (C) Bildarchiv Foto Marburg/Lala Aufsberg) and Kuhn (1921, p. 105). 
template for urban renewal in Germany, which Heimatinspired urbanists described disparagingly as a "cult of the street." The image of Paris as an emblem of cultural modernity would soon be challenged by the increasing influence of the English garden city movement in Germany, which brought housing to the center of debate. Planners Raymond Unwin and Barry Parker's urban designs for the garden suburbs of Letchworth and Hampstead, which incorporated low-density, low-rise small houses inspired by the Arts and Crafts movement, were praised by German architects like Hermann Muthesius for their sensitivity to context and local tradition (Eberstadt, 1909a; Muthesius, 1904-5/1979).

If critics like Muthesius praised the typological clarity of the "English house" and proposed it as an ideal suburban vernacular, a comparable "German house" still awaited discovery (Stalder, 2008). Founded in 1903 by German architect Theodor Goecke and Sitte (who died before the first issue's release), the journal Der Städtebau became a vital organ for reporting on English developments, provoking debate about how international garden city ideals could adapt to local conditions. In a message to their readers in the journal's inaugural issue, Goecke and Sitte declared that, amongst other tasks such as regulating traffic, providing healthy and comfortable dwellings, and accommodating industry, a chief goal of the nascent field of urban planning was to nurture a "true love of Heimat" (1904, p. 1).

While not one to wax lyrical about the beauty of his native town (the city of Worms), the economist Rudolf Eberstadt became a central figure in promoting a localist ethic in city planning circles, whilst recognizing the need to systematize knowledge of house forms in ways practicable for planning authorities. Eberstadt's influential Handbuch des Wohnungswesens und der Wohnungsfrage [Handbook for Housing and the Housing Question] (1909b) proved critical in giving terminological precision to housing forms at the intersection of architectural and planning cultures. Prior to the handbook's publication, there existed no term in the German language that could be considered akin to the now-prevalent English term "housing," used to describe a relatively autonomous field of knowledge. The term Wohnung (dwelling) was most frequently used in political, statistical, and social-scientific fields to describe the household unit. The emergence of the Wohnungsfrage (literally the "dwellings question") in the late 19th century was largely limited to the arena of political debate between bourgeois reformists over how best to balance economical demands with concerns to improve the moral lives of the lower classes (Bernhardt, 1998; Bullock \& Read, 1985; Kastorff-Viehmann, 1979).

Eberstadt offered a progressive voice on the housing question, sympathizing with the working classes and emphasizing the need for comprehensive planning to curb private speculation. At the same time, he betrayed a more typical bourgeois conservatism in his willingness to draw sharp lines between the normal and the patho- logical to explain housing conditions. In the introduction, he explained that:

The science of dwelling circumstances has, like medicine, its physiology and its pathology; it is an investigation of normal and abnormal conditions; it must recognize and acknowledge both. The investigation of the general normal conditions is the job of housing [Wohnungswesen, literally "the business of dwelling"]; the understanding and explanation of individual anomalous, unsatisfactory, sick conditions is the area of the housing question [Wohnungsfrage]....The housing question and housing have thus the same external area in common, but their methods and goals are different. The science of housing has, as I would like to define here, the goal of realizing the best conditions for the production, use, and assessment of human dwelling. (Eberstadt, 1910, pp. 1-2)

In his efforts to establish housing as a rigorous science, Eberstadt developed a typo-morphological approach that would become a mainstay in urban design research, providing urban street, block, and dwelling typologies that could standardize communication across the architectural and planning fields (Albrecht \& Zurfluh, 2019; Claessens, 2004). Historical research formed a crucial part of this approach. In the first section of the Handbook, Eberstadt traced the evolution of small housing construction back to Antiquity. His cultural frame of reference was narrow, idealizing the archetypal twostory, three-window house that served rapidly growing urban communities across the Germanic lands from the 12th century onwards, which he termed the Kleinhaus (although none from this century survived).

While this term was hitherto occasionally (and ambiguously) used in late 19th-century housing literature simply to describe a small dwelling detached on all sides, analogous to the English "cottage," in Eberstadt's hands, it came to be infused with a sense of stylistic clarity, aesthetic purpose, and national historical fate. Emphasizing close ties between this simple, schematic house type and the socio-economic context of homeownership and urban belonging, the economist went as far as to suggest that its introduction was of "far-reaching importance" to the political and economic development of the middle-classes during the Middle Ages (Eberstadt, 1910, p. 41).

In another sub-section on the "Artistic consideration of house forms," Eberstadt reproduced the Kleinhaus model copiously in photographs of a handful of stillsurviving pre-modern philanthropic complexes, including Augsburg's Fuggerei, Lübeck's dwelling corridors, and Ulm's militia housing-models which he held to be ideal (Eberstadt, 1910, pp. 204-211). As cities of declining economic importance and increasing touristic value in the 19th century, the sense of longing for Heimat is palpable in their visual presence in the Handbook. At the same 
time, they betray a somewhat patronizing gaze on the modest lifestyles of the traditional underclasses. Many of the houses reproduced in the Handbook appeared derelict, bearing significant resemblance to the backto-back terraces that were simultaneously being condemned in England for their poor ventilation. Hygienic concerns aside, for Eberstadt these models told a story of historical continuity and gradual organizational perfection according to the distinct social requirements of the hard-working family. As such, they reflected more than poor housing-they encapsulated a reformist impulse that was authentically middle-class in its aspirations to eschew outward ostentation and strive for autonomy, familial comfort, and privacy.

As a house form that could be detached, duplex, or terraced, the Kleinhaus as an ideal "normal" dwelling challenged the established hierarchy of values in the housing debate that positioned the economic value of the high-density tenement model against the moral and hygienic value of the low-density cottage model. Defining the healthy dwelling became less a matter of density and more a matter of historical authenticity and conventionalism. Typo-morphological correctness according to historical precedent would naturally bring all external factors shaping the healthy dwelling into equilibrium. The architectural merit of a house was defined by its capacity to render its social content legible. Tenement buildings, Eberstadt argued, were not capable of developing their own artistic sensibility. They could be covered with columns and caryatids and "still appear much uglier because they appear more untrue. The dwelling house must express its purpose, to belong to the person, to offer him freedom, security and possession, and only where these conditions are fulfilled can the external form become artistically well designed" (Eberstadt, 1910, p. 257). To illustrate his point, Eberstadt reproduced an image of a typical tenement building beside a complex of Kleinhäuser (Figure 6). The differences for readers of the Handbook were intended to be stark: On the left stood a façade shielding an indiscriminate mass of living space; on the right stood houses that demonstrated full correspondence between social content and exterior form.

After Eberstadt's Handbook, images of rustic pitched roofs and picturesque streets went from being scattered fragments appreciated strictly by Heimat enthusiasts to concrete strategies in the urban planner's toolbox. Underlying the pragmatism of this endeavor lay a deeper impulse to fashion myths about the long-durée of modern social housing-a history structured by the secularization of the philanthropic institution and the rise of global trade cities in the early modern world. By privileging the Kleinhaus as the standard for "normal" modern housing conditions, the Handbook placed the historical autonomy of the traditional urban middle-classes at the center of an urban design agenda in Germany, whilst making this house form operative in responding to the logic of future metropolitan growth. In contrast to the planning of the tenement city as a veritable Potemkin village, modern urban planning became a matter of grasping how the "big city" (Großstadt) as an organism interacted with the Kleinhaus as its most basic cell.

\section{Fabricating the Kleinhaus}

In the decade following the publication of the Handbook, the term Kleinhaus became ubiquitous in architectural and planning discourse. As the closest thing to a national

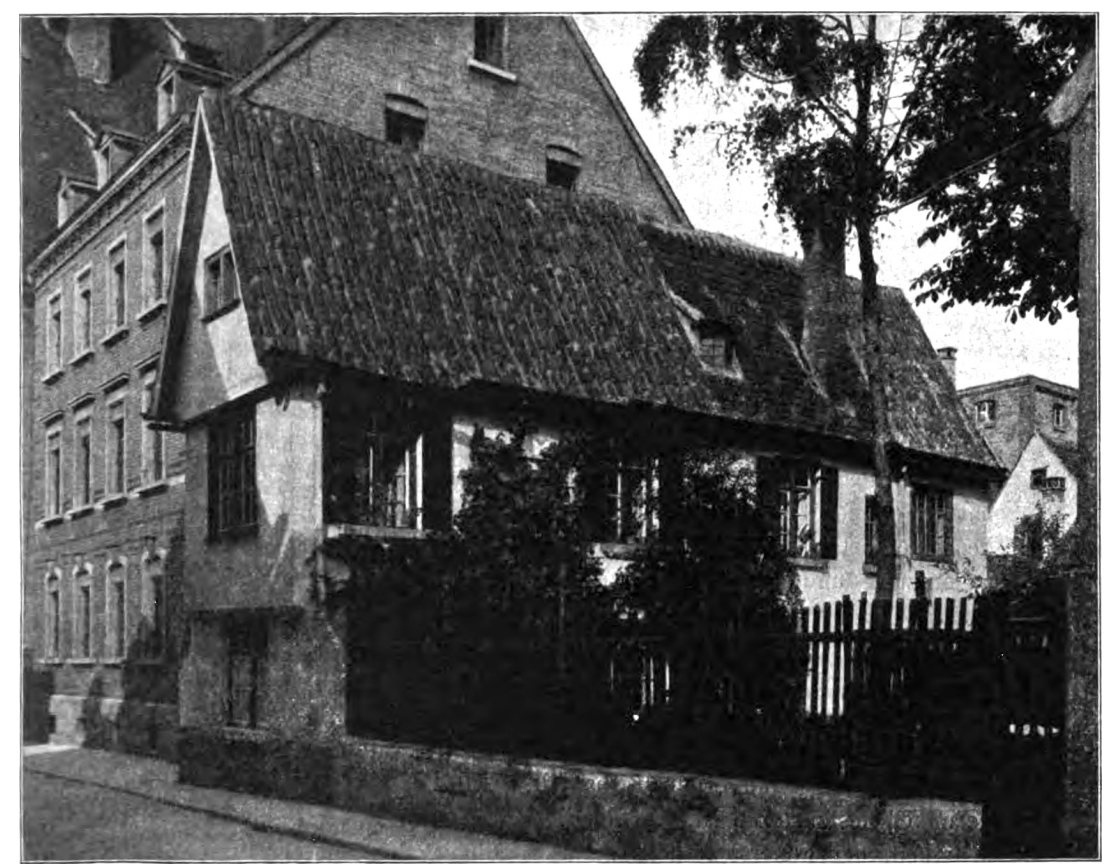

Figure 6. Comparison of an apartment complex and a row of Kleinhäuser. Source: Eberstadt (1910, p. 259). 
type, it came to express the same level of stylistic clarity and sense of middle-class virtue as the "English house" (Breuer, 1914; Former, 1912; Muthesius, 1918). Much like the English house, the problem posed by the Kleinhaus was that of finding a balance between monotonous standardization and the saccharine picturesqueness of typical Heimat art. In his post-war handbook Kleinhaus und Kleinsiedlung [Kleinhaus and Small Settlement], Muthesius (1918, p. 227) argued that the Kleinhaus, as an organically evolved object, "recalls the perfection that our machines, weapons, and airplanes experience through continued progress in manufacture." He assured his readers that the monotony created out of its progressive standardization-from its window frames to its floor plan-would necessarily be tempered when adapted to local (örtlich) idiom, and would thus never be boring (1918, p. 224-231).

Muthesius singled out a few large housing projects, including the garden cities of Hellerau and Staaken, as chief representatives of modern Kleinhaus construction. These garden cities successfully evoked the romantic image of the small town in their architectural conventions (albeit largely perverting traditional examples through their weakened social connections to the city). Founded in 1908 and financially aided by the Hellerau Building Cooperative, the Hellerau garden city, just outside of Dresden, provided cheap rent or homeownership to the working and lower-middle classes. Likely for the purposes of cost and heating insulation, nearly all construction in Hellerau consisted of low-rise row houses. Architect Heinrich Tessenow produced the most infamous designs in his contribution to Hellerau, stripping the Kleinhaus back to its essential elements as a lesson in middle-class self-restraint (Ekici, 2013). Other contributions by notable architects Georg Metzendorf, Richard Riemerschmid, Muthesius, and Kurt Frick emphasized the more local traditionalistic elements of the Kleinhaus model (Figure 7), incorporating eyelid dormers and rustic roof shingles and shutters.

While the balance between asceticism and romanticism proved delicate amongst the architects involved, all of the houses in Hellerau encapsulated the social ethos underpinning the historical Kleinhaus model in their commitment to achieving a rationalism and conciseness in floor plan. All emanated an enclosed and complete familial existence between their four walls. Muthesius's floor plans demonstrated a rationalized coordination of rooms according to the needs of the family, recalling the typification processes that guided the design of the Fuggerei. These plans featured all the conventional elements of family living, including the scullery, water closet, kitchencum-living room (Wohnküche), a separate living room on the ground floor, and the parents' bedroom and separate children's bedrooms according to gender on the upper floor (Figure 8). The private gardens attached to Muthesius's dwellings were also distinctly no-fuss and practical, containing stables for livestock.

Constructed by the Imperial Office of the Interior (Reichsamt des Innern) to house local factory workers in munition production, the Staaken colony near Spandau, Berlin (1914-1917) by architect Paul Schmitthenner was an ambitious experiment in floor plan standardization (right down to its door handles; Oppenheimer, 1917, p. 8). It featured just five variations in plan across 800 dwellings, all of which were modest in size but featured a generous kitchen-cum-living room as the central



Figure 7. Photograph of Riemerschmid's housing group on the street “Am grünen Zipfel.” Source: Breuer (1911, p. 458). 


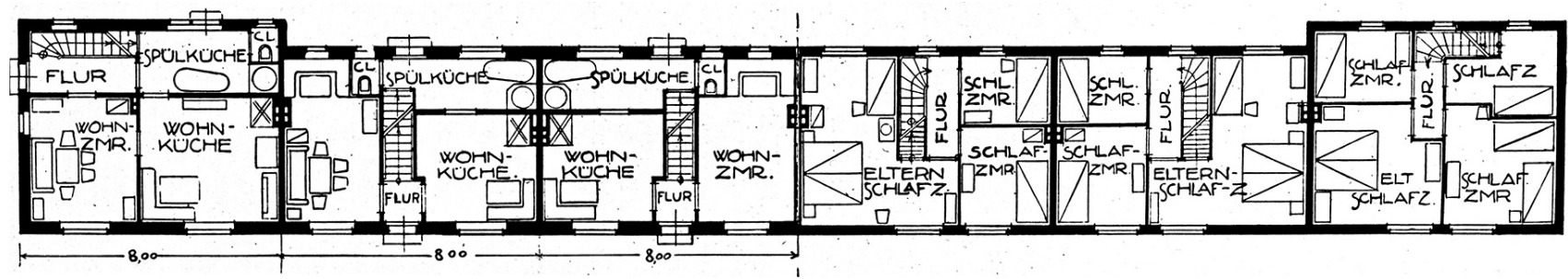

Figure 8. Muthesius' floor plans for a housing group in Hellerau, 1909. From the collection of Franz Stoedtner. Source: "Grundriß der Häusergruppe "Beim Gräbchen" in Hellerau" [Plan of a housing group "Beim Gräbchen" in Hellerau] (1909), (C) Bildarchiv Foto Marburg.

family hearth and a private yard big enough for livestock (Voigt, 2012, p. 18). Schmitthenner's various façade designs cited traditional decorative features of northern German old towns, from a Dutch gabled Baroque style to a more restrained classicism (Figure 9). Far from turning the colony into a pastiche of historical quotation, the overriding pragmatic demands of the Kleinhaus as a basic socio-aesthetic model kept them homey but restrained. Equally significant was the incorporation of artistic urban design principles, such as gates that enclosed streets and reasserted an interior-like character-in effect relocating Sittean principles from the church and square to the residential community as the new locus of civic life.

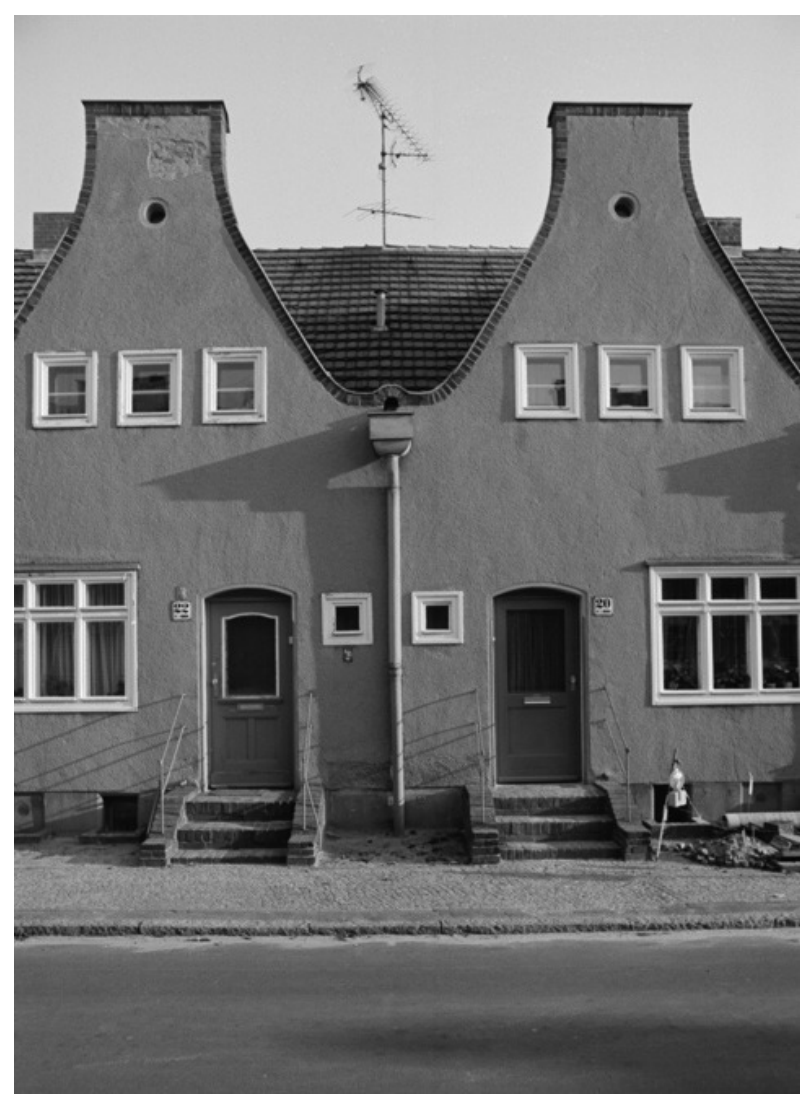

Figure 9. Schmitthenner's housing on the street "Zwischen den Giebeln" in the Staaken garden city, Spandau, Berlin. Source: Vorsteher (1978), C Bildarchiv Foto Marburg/Dieter Vorsteher.
For conservative critics, Staaken successfully captured the civic spirit of the traditional Brandenburg village without feeling imitative (Schmitz, 1919; Stahl, 1917).

Further west, architect Hugo Wagner's designs for workers' housing near Bremen (Maraun, 1995) were similarly praised by architectural critics for incorporating a rustic local idiom whilst reflecting a modernist sensibility through their commitment to decorative restraint and uniformity. Wagner was a vocal promoter of the movement for Heimat protection (Heimatschutz) in Bremen, and traditionalist critics positioned his work within an organic lineage of authentic northern German Kleinhaus construction (Eberstadt, 1910, pp. 254-255; Högg, 1909; Seeßelberg \& Lindner, 1909). His private projects, which included cheap and rustic duplex housing in the workers' colonies of Einswarden (1908) and Burg-Grambke (1910; Figure 10), might have easily been mistaken for surviving remnants of an early housing foundation project. The strictness of their uniform façades was offset by alternations of densities and gable configurations that gave rhythm and variety to the streetscape. Wagner's standardized floor plan designs played an equally reformist role in providing a generous kitchencum-living room to serve as a family hearth (Figure 11). Family-oriented reformists praised the adjoined ventilated stove and sink area, which maintained health standards whilst enabling the housewife to sufficiently oversee household activity (Kelm, 1911, p. 142).

While all of these modern emulations of the Kleinhaus interpreted the model differently according to local tradition, what united them was a shared commitment to standardize the floor plan based on what they perceived to be the glue holding urban society together: the family hearth. In his praise of new suburban developments including Hellerau and Staaken, critic Walter Curt Behrendt maintained that the "kitchen forms the real center of family traffic in the Kleinhaus. Here the housewife controls, the children play, the meals are taken, the family is brought together around the 'domestic hearth' during the free hours of the evening, like the times of the old German middle-class houses [Bürgerhauses]" (1916, p. 208). In its ability to mold the worker into an upright citizen, Behrendt (1916, p. 228) argued that the suburban Kleinhaus, with its hearth and vegetable patch, "creates a bond that binds the population to the soil of the fatherland once more." 


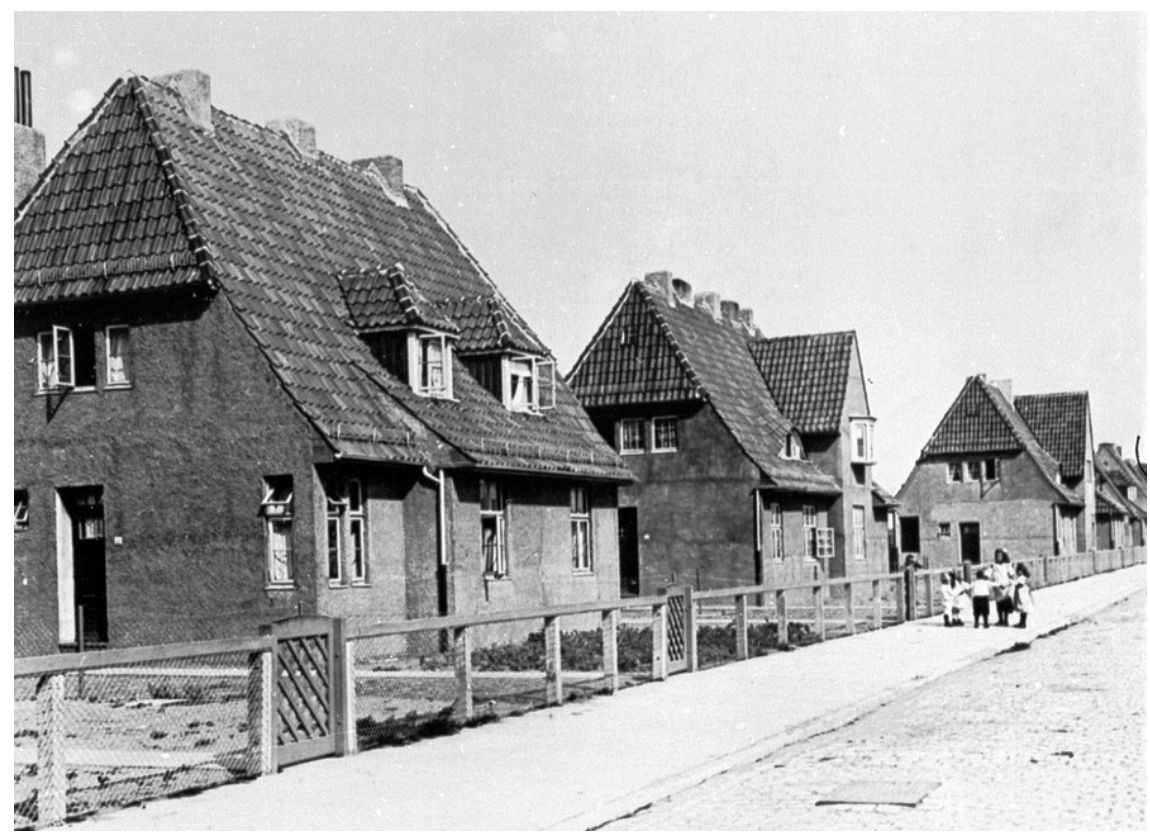

Figure 10. Wagner's housing for workers in Burg-Grambke, Bremen, 1910. From the collection of Franz Stoedtner. Source: "Arbeiterkolonie" [Workers' Colony] (n.d.), (c Bildarchiv Foto Marburg.

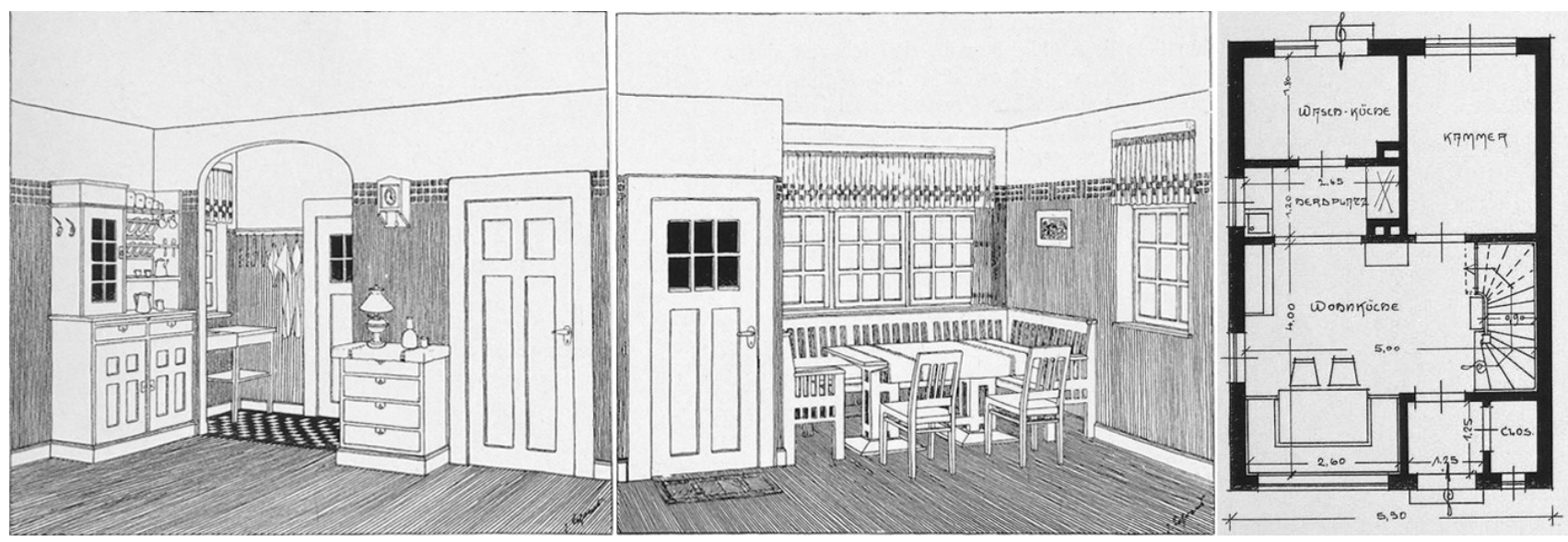

Figure 11. Wagner, Lotz, and Schacht's designs for the workers' colony of Einswarden, Bremen. Left and center illustrates the kitchen-cum-living room and right illustrates the floor plan. Source: Seeßelberg and Lindner $(1909$, p. 45).

\section{Conclusion}

While this house model lost much of its cultural import in the 1920s as new terms like the "minimum dwelling" (Existenzminimum) gained momentum in modernist circles and sidelined traditionalist positions, it continued to serve as an aspirational object for the nation's lower middle-classes and remained the dominant house type in Germany well into the 1960s (Lorbek, 2018). By examining the emergence of the Kleinhaus in professional and popular discourse, this article has sought to demonstrate that, in Germany at least, efforts to clarify housing terminology around singular ideals were closely tied to the process of nation-building. In its ability to mobilize national historical myths about civic responsibility and local belonging, the Kleinhaus remained a central part of early 20th-century efforts to address Germany's hous- ing shortage (Muthesius, 1918; Wolf, 1919). Its historical rediscovery, codification, and fabrication involved energetic cross-disciplinary dialogue between the fields of art history, architecture, and planning. It was a dialogue that reflected, foremost, cultural anxieties over carving a place for the local out of an increasingly homogenous template of European modernity.

\section{Conflict of Interests}

The author declares no conflict of interests.

\section{References}

Ackerman, J. S. (2002). On the origins of architectural photography. In K. Rattenbury (Ed.), This is not architecture: Media constructions (pp. 26-36). Routledge. 
Adam, T. (2016). Philanthropy, civil society, and the state in German history, 1815-1989. Boydell \& Brewer.

Albrecht, K., \& Zurfluh, L. (2019). Between decoding and recoding: Raymond Unwin's “Town planning in practice" and Rudolf Eberstadt's "Handbook des Wohnungswesens" as means of reflection and regulation. In B. Hentschel \& H. R. Stühlinger (Eds.), Recoding the city: Thinking, planning, and building the city of the nineteenth century (pp. 119-137). Jovis.

Applegate, C. (1990). A nation of provincials: The German idea of Heimat. University of California Press.

Arbeiterkolonie [Workers' Colony]. (n.d.). Photograph (Number 1.061.947). Bildarchiv Foto Marburg, Marburg, Germany.

Aufsberg, L. (1939). Photograph (Number 715.642). Bildarchiv Foto Marburg, Marburg, Germany.

Baum, J. (1912). Die schöne deutsche Stadt: Süddeutschland [Beautiful German cities: South Germany]. R. Piper.

Baycroft, T., \& Hopkin, D. (Eds.). (2012). Folklore and nationalism in Europe during the long nineteenth century. Brill.

Behrendt, W. C. (1916). Kleinsiedlungen [Small settlements]. Dekorative Kunst, 19(7), 205-228.

Bernhardt, C. (1998). Bauplatz Groß-Berlin: Wohnungsmärkte, Terraingewerbe und Kommunalpolitik im Städtewachstum der Hochindustrialisierung (1871-1918) [Construction site Greater Berlin: Housing markets, land development, and local politics in the period of rapid industrialisation (1781-1918)]. de Gruyter.

Blackbourn, D., \& Retallack, J. (Eds.). (2007). Localism, landscape, and the ambiguities of place: Germanspeaking central Europe, 1860-1930. University of Toronto Press.

Breuer, R. (1911). Die Gartenstadt Hellerau [The Hellerau garden city]. Deutsche Kunst und Dekoration, 6(4), 447-465.

Breuer, R. (1914). Das bürgerliche Kleinhaus [The middleclass Kleinhaus]. Innen-Dekoration, 25(1), 47-54.

Bruns, F. (1920). Lübeck: Ein Führer durch die freie und Hansestadt und ihre nähere Umgebung [Lübeck: A guide through the free and Hanseatic city and its immediate surroundings]. Verein zur Hebung des Fremdenverkehrs.

Buchkremer, M. (2013). Stoedtner, Franz. In Neue deutsche Biographie [New German biography] (vol. 25, pp. 386-387). Duncker \& Humblot.

Bullock, N., \& Read, J. (1985). The movement for housing reform in Germany and France, 1840-1914. Cambridge University Press.

Claessens, F. (2004). Rudolf Eberstadt, a pioneer of German typo-morphological research. In F. Claessens \& L. van Duin (Eds.), The European city: Architectural interventions and transformations (pp. 360-369). Delft University Press.

Eberstadt, R. (1909a). Die neue Gartenvorstadt in London-Hampstead [The new garden suburb in
London-Hampstead]. Der Städtebau, 6(8), 99-103.

Eberstadt, R. (1909b). Handbuch des Wohnungswesens und der Wohnungsfrage [Handbook for housing and the housing question]. Gustav Fischer.

Eberstadt, R. (1910). Handbuch des Wohnungswesens und der Wohnungsfrage [Handbook for housing and the housing question] (2nd ed.). Gustav Fischer.

Ekici, D. (2013). In praise of poverty: The middle-class dwelling and asceticism in early twentieth-century Germany. Journal of Architecture, 18(3), 364-380.

Essenwein, A. (1892). Die romanische und gothische Baukunst: Der Wohnbau [Romanesque and Gothic architecture: Residential building]. Bergsträsser.

Former, A. (1912). Großstadt und Kleinhaus [Metropolis and Kleinhaus]. Architektonische Rundschau, 28(12), 45-48.

Gandorps Gang - Hof [Gandorps Gang - Courtyard]. (1925). Photograph (Number 835.428). Bildarchiv Foto Marburg, Marburg, Germany.

Goecke, T., \& Sitte, C. (1904). An unsere Leser [To our readers]. Der Städtebau, 1(1), 1-4.

Grundriß der Häusergruppe "Beim Gräbchen" in Hellerau [Plan of a housing group "Beim Gräbchen" in Hellerau]. (1909). Photograph (Number 1.096.722). Bildarchiv Foto Marburg, Marburg, Germany.

Harms, L. W. (1907). Höfe und Gänge in Lübeck [Courtyards and corridors in Lübeck]. Der Städtebau, 4(11).

Högg, E. (1909). Bremen im Kampfe um die heimische Bauweise [Bremen in the struggle for a local architecture]. Wochenschrift des Architekten-Vereins zu Berlin, 4(38), 191-194.

Jenkins, J. (2003). Provincial modernity: Local culture and liberal politics in fin-de-siècle Hamburg. Cornell University Press.

Jerram, L. (2007). Germany's other modernity: Munich and the making of metropolis, 1895-1930. Manchester University Press.

Joschke, C., \& Brown, Z. (2012). The origins of the social usage of photography. Art in Translation, 4(3), 335-359.

Kastorff-Viehmann, R. (1979). Kleinhaus und Mietkaserne [Kleinhaus and tenement]. In L. Niethammer (Ed.), Wohnen im Wandel: Beiträge zur Geschichte des Alltags in der bürgerlichen Gesellschaft [Dwelling in transformation: Contributions to the history of the everyday in civil society] (pp. 271-291). Peter Hammer.

Kelm, A. (1911). Beiträge zur Wohnungsreform unter besonderer Berücksichtigung des Kleinwohnungsbaus [Contributions to dwelling reform with particular consideration of small dwelling construction]. G. Fischer.

Kohlmorgen, G. (1982). Johann Füchting und Füchtingshof in Lübeck: Ein Beispiel für die Anfänge sozial wirkenden Kleinwohnungsbaus [Johann Füchting and Füchtingshof in Lübeck: An example of the beginnings of socially operative small dwelling construction]. Schmidt-Römhild. 
Kuhn, W. (1921). Kleinbürgerliche Siedlungen in Stadt und Land [Lower-middle-class settlements in city and country]. Callwey.

Lampugnani, V. M. (2009). Vienna fin-de-siècle: Between artistic city planning and unlimited metropolis. In C. C. Bohl \& J.-F. Lejeune (Eds.), Sitte, Hegemann and the metropolis: Modern civic art and international exchanges (pp. 25-37). Routledge.

Lampugnani, V. M., \& Schneider, R. (1992). Moderne Architektur in Deutschland 1900 bis 1950: Reform und Tradition [Modern architecture in Germany 1900 to 1950: Reform and tradition]. G. Hatje.

Lorbek, M. (2018). Idealizations of the Kleinhaus: On the typology of the small single-family house in Germany, 1920s-1960s. Architectural Histories, 6(1), 1-17.

Maraun, H. (1995). Hugo Wagner (1873-1944): Ein Architekt der Reformbewegung [Hugo Wagner (1873-1944): An architect of the reform movement]. Simmering.

Mebes, P. (1908). Um 1800: Architektur und Handwerk im letzten Jahrhuntert ihrer traditionallen Entwicklung [Around 1800: Architecture and craft in the last decade of its traditional development] (Vols. 1-2). F. Bruckmann.

Miller-Lane, B. (2000). National romanticism and modern architecture in Germany and the Scandanavian countries. Cambridge University Press.

Muthesius, H. (1918). Kleinhaus und Kleinsiedlung [Kleinhaus and small settlement]. F. Bruckmann.

Muthesius, H. (1979). The English house. Crosby Lockwood Staples. (Original work published 1904-5).

Oppenheimer, F. (1917). Introduction. In P. Schmitthenner (Ed.), Die Gartenstadt Staaken [Staaken garden city] (pp. 3-8). Wasmuth.

Redensek, J. (2017). Zur Rezeption des Bauernhauses durch die Architekten der Moderne in Deutschland um 1900 [On the reception of the farmhouse by architects of the modern movement in Germany around 1900]. Zeitschrift für Kulturwissenschaften, 11(1), 49-72.

Rollins, W. R. (1997). A greener vision of home: Cultural politics and environmental reform in the German Heimatschutz Movement, 1904-1918. University of Michigan Press.

Rousset, I. (in press). The architecture of social reform: Housing, tradition and German modernism. Manchester University Press.

Schmitz, H. (1919). Die Gartenstadt Staaken [Staaken garden city]. Dekorative Kunst, 22(8), 221-232.

Schnelbögl, F. (1961). Die Webersiedlung "Sieben Zeilen" auf dem Schwabenberg [The weavers' settlement "Seven Rows" in Schwabenberg]. In K. Goldmann (Ed.), Norica: Beiträge zur Nürnberger Geschichte [Norica: Contributions to Nuremberg history] (pp. 69-75). Stadtbibliothek Nürnberg.

Schultze-Naumburg, P. (1906). Kulturarbeiten: Der
Städtebau [Cultural works: City planning]. Callwey.

Schwarzer, M. (2016). The sources of architectural nationalism. In R. Quek, D. Deane, \& S. Butler (Eds.), Nationalism and architecture (pp. 19-38). Routledge.

Seeßelberg, F., \& Lindner, W. (1909). Moderne niedersächsische Bauweise [Modern architecture of Lower Saxony]. Architektonische Rundschau, 25(6), 41-48.

Sieben Zeilen [Seven Rows]. (1918). Photograph (Number 618.533). Bildarchiv Foto Marburg, Marburg, Germany.

Sitte, C. (1889). Die Städtebau nach seinen künstlerischen Grundsätzen [City planning according to artistic principles]. Carl Grakser.

Soldatenhäuser [Soldiers' Housing]. (1900). Photographs (Numbers 1.096.480/1.096.482). Bildarchiv Foto Marburg, Marburg, Germany.

Stahl, F. (1917). Die Gartenstadt Staaken [Staaken garden city]. In P. Schmitthenner (Ed.), Die Gartenstadt Staaken [Staaken garden city] (pp. 9-15). Wasmuth.

Stalder, L. (2008). Hermann Muthesius, 1861-1927: Das Landhaus als kulturgeschichtlicher Entwurf [Hermann Muthesius, 1861-1927: The country house as cultural-historical project]. gta Verlag.

Stiehl, O. (1908). Der Wohnbau des Mittelalters [Residential architecture of the Middle Ages]. Kröner.

Stübben, J. (1890). Der Städtebau [City planning]. Arnold Bergstrasser.

Tietz-Strödel, M. (1982). Die Fuggerei in Augsburg: Studien zur Entwicklung des sozialen Stiftungsbaus im 15. und 16. Jahrhundert [The Fuggerei in Augsburg: A study of the development of the social philanthropic complex in the 15th and 16th centuries]. J. C. B. Mohr.

Umbach, M. (2009). German cities and bourgeois modernism, 1890-1924. Oxford University Press.

Umbach, M., \& Hüppauf, B.-R. (2005). Vernacular modernism: Heimat, globalization, and the built environment. Stanford University Press.

Voigt, W. (2012). Modern in intention? Paul Schmitthenner revisited. In DASH \#06-Living in a new past (pp. 16-33). NAi.

Vorsteher, D. (1978). Gartenstadt Staaken [Staaken garden city]. Photograph (Number LA 3.892/24). Bildarchiv Foto Marburg, Marburg, Germany.

Weidenbacher, J. (1918). Die Fuggerei in Augsburg [The Fuggerei in Augsburg]. Der Städtebau, 15(1), 3-9.

Wolf, G. (1911). Die schöne deutsche Stadt: Mitteldeutschland [Beautiful German cities: Central Germany]. R. Piper.

Wolf, G. (1913). Die schöne deutsche Stadt: Norddeutschland [Beautiful German cities: North Germany]. R. Piper.

Wolf, P. (1919). Die Kleinwohnung-Ein Forderung künftiger deutscher Baukultur [The small dwelling: A demand for the German building culture of the future]. Der Cicerone, 11, 174-181. 


\section{About the Author}

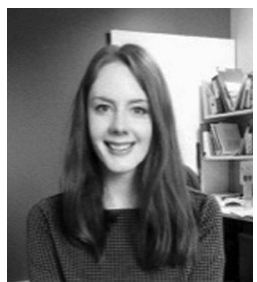

Isabel Rousset is an architectural historian and teacher at Curtin University. Her research focusses on the intersections of architecture and social politics in the nineteenth and early twentieth centuries. Her book The Architecture of Social Reform: Housing, Tradition and German Modernism is forthcoming with Manchester University Press. She has also published on the topic of German modernism in the Journal of Architecture, the Journal of Urban History, and Architectural Theory Review. 